\title{
Distribution of forms of potassium in soils of central and eastern Vidarbha region of Maharashtra
}

SHILPABABAR, P.K. RATHOD, V.G. SALVI AND V.P. BADOLE

Received : 20.08.2014; Revised : 09.04.2015; Accepted : 18.04.2015

MEMBERS OF RESEARCH FORUM:

Corresponding author : P.K. RATHOD, Krishi Vigyan Kendra, College of Agricuture, DHULE (M.S.) INDIA

Co-authors : SHILPA BABAR, V.G. SAL VI AND V.P. BADOLE, Krishi Vigyan Kendra, College of Agricuture, DHULE (M.S.) INDIA

\section{Summary}

Soil samples from fourteen profiles from five districts of Central and Western Vidarbha region of Maharashtra were studied for the distribution of different forms of potassium and for their relationship with some soil properties. The soils of Wardha, Nagpur, Chandrapur and Bhandara districts were slightly calcarious neutral to alkaline in reaction and the soils of Gondia district was non-calcarious and sightly acidic in reaction. The Central Vidarbha soils were clay in texture having high in organic carbon content. Whereas the soils of Eastern Vidarbha were clay loam, sandy clay loam and low in organic carbon content. No definite trend was observed in the forms of potassium except exchangeable and available $\mathrm{K}$, they were decreased with increase in depth. The available $\mathrm{K}$ and exchangeable $\mathrm{K}$ increased with the increase in organic carbon $\left(\mathrm{r}=0.4680^{* *}, \mathrm{r}=0.4526^{* *}\right)$. The availability of exchangeable $\mathrm{K}$ increased with increase in clay content $\left(\mathrm{r}=0.2888^{* *}\right)$. The non-exchangeable $\mathrm{K}$ was also increased with clay content $\left(\mathrm{r}=0.7141^{* *}\right)$ and EC $\left(\mathrm{r}=0.6444^{* *}\right)$ in Eastern Vidarbha region. The availability of total $\mathrm{K}$ and lattice $\mathrm{K}$ increased with increase in organic carbon $\left(\mathrm{r}=0.4303^{* *}, \mathrm{r}=0.4785^{*}\right)$ and clay content $\left(\mathrm{r}=0.5189^{*}, \mathrm{r}=0.4631^{*}\right)$ in Eastern Vidarbha region of Maharashtra.

Key words : Distribution pattern, Forms of soil K, Soil depth, Relationship with soil properties!

How to cite this article : Babar, Shilpa, Rathod, P.K., Salvi, V.G. and Badole, V.P. (2015). Distribution of forms of potassium in soils of central and eastern Vidarbha region of Maharashtra. Asian J. Soil Sci., 10(1) : 34-41. 